\title{
Determination of Vestibulo-ocular Reflex Gain Normal Values in Children with Video Head Impuls Test
}

\author{
Çocuklarda Video Kafa İtme Testi ile Vestibülo-oküler Refleks Kazanç Normal \\ Değerlerinin Belirlenmesi
}

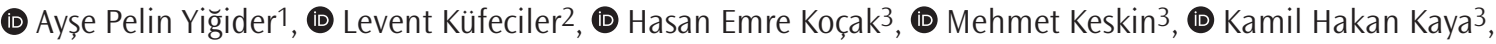 \\ (1) Arzu Karaman Koç3, (1) Mustafa Suphi Elbistanlı3 \\ 1 University of Health Sciences Turkey, İstanbul Training and Research Hospital, Clinic of Otolaryngology, İstanbul, Turkey \\ 2University of Health Sciences Turkey, Bakırköy Dr. Sadi Konuk Training and Research Hospital, Clinic of Audiology, İstanbul, Turkey \\ 3University of Health Sciences Turkey, Bakırköy Dr. Sadi Konuk Training and Research Hospital, Clinic of Otolaryngology, ístanbul, Turkey
}

\begin{abstract}
Introduction: Video head impuls test (VHIT) is used in the diagnosis of vestibular dysfunction. There is no study conducted on VHIT application and its results on children in our country. Our study aimed to examine vHIT tests in children with normal hearing function and to determine normal value ranges.

Methods: This study was made up of a total of 78 children under 16 years of age with normal hearing function. All children received VHIT and the values found were recorded.

Results: Of the 78 children participating in the study, 44 (56.4\%) were boys and $34(43.6 \%)$ were girls. There was no significant difference in the results of vHITs between the ages of 4-6, 7-9 and 10-12 in terms of mean left lateral, right lateral, left anterior, right posterior, left posterior and right anterior values ( $p>0.05$ for each). However, in the analysis performed by combining 4-12 age groups, there was a significant difference between the ages of 4-12 and 12 years in terms of left posterior mean values $(p=0.012)$.

Conclusion: When the findings of our study and combined reports were evaluated, it was observed that normal vestibuloocular reflex gain values should be determined in the paediatric population by the VHIT method. We consider that, paediatricians may use the findings of our study as guide for the evaluation of vestibular function in children. Extensive studies are needed to ensure that the normal value ranges reach a higher level of reliability.
\end{abstract}

Keywords: Child, vertigo, video head impuls test, vHIT, vestibulo-ocular reflex

\section{öZ}

Amaç: Video kafa itme testi (VHIT) vestibüler fonksiyon bozukluğu tanısında kullanılmaktadır. Ülkemizde çocuklar üzerinde vHIT uygulaması ve sonuçları ile ilgili bir çalışma henüz bulunmamaktadır. Çalışmamızda normal ișitme fonksiyonuna sahip çocuklarda vHIT testlerinin irdelenmesi ve normal değer aralıklarının belirlenmesi amaçlanmıștır.

Yöntemler: Çalıșmaya normal işitme fonksiyonuna sahip 16 yaş altı olan toplam 78 çocuk dahil edilmiştir. Tüm çocuklara vHIT uygulanmış ve bulunan değerler kaydedilmiștir.

Bulgular: Çalışmaya katılan çocukların 44'ü $(\% 56,4)$ erkek, 34'ü $(\% 43,6)$ kız idi. vHIT sonuçlarında 4-6, 7-9 ve 10-12 yaş grupları arasında ortalama sol lateral, sağ lateral, sol anterior, sağ posterior, sol posterior ve sağ anterior değerleri açılarından anlamlı fark yoktu (her biri için $p>0,05$ ). Ancak 4-12 yaş gruplar birleștirilerek yapılan analizde 4-12 yaș ile 12 üzeri yaş grubu arasında sol posterior ortalama değerleri açısından anlamlı fark saptandı $(p=0,012)$.

Sonuç: Çalışmamız bulguları ile yayınlanmış raporlar birleștirilerek değerlendirildiğinde, pediatrik popülasyonda vHIT yöntemi ile normal vestibülo-oküler refleks kazanç değerlerinin belirlenmesi gerekliliği görülmüștür. Çalıșmamız bulgularının pediatristlerce çocuklarda vestibüler fonksiyon değerlendirilmesinde yol gösterici olabileceği düşüncesindeyiz. Normal değer aralıklarının daha yüksek güvenilirlik düzeyine ulaşması için daha geniş çalıșmalara gereksinim bulunmaktadır.

Anahtar Kelimeler: Çocuk, vertigo, video kafa itme testi, vHIT, vestibülo-oküler refleks
Address for Correspondence/Yazıșma Adresi: Ayșe Pelin Yiğider MD, University of Health Sciences Turkey, Istanbul Training and Research Hospital, Clinic of Otolaryngology, İstanbul, Turkey

Phone: +90 5324109025 E-mail: pelin.gor@gmail.com ORCID ID: orcid.org/0000-0002-4206-0074

Cite this article as/Atıf: Yiğider AP, Küfeciler L, Koçak HE, Keskin M, Kaya KH, Karaman Koç A, Elbistanlı MS. Determination of Vestibulo-ocular Reflex Gain Normal Values in Children with Video Head Impuls Test. İstanbul Med J 2020; 21(6): 413-417.

(c) Copyright 2020 by the University of Health Sciences Turkey, Istanbul Training and Research Hospital/istanbul Medical Journal published by Galenos Publishing House.

(C) Telif Hakkı 2020 Sağıı Bilimleri Üniversitesi Istanbul Ĕgitim ve Araştırma Hastanesi/Istanbul Tıp Dergisi, Galenos Yayınevi tarafından basılmıștır.
Received/Geliș Tarihi: 09.04.2020 Accepted/Kabul Tarihi: 11.08 .2020 


\section{Introduction}

Dizziness is known as the feeling or illusion that the person or his environment is moving. Although the term vertigo is sometimes used instead of just dizziness, vertigo is defined as a sendrom presenting with several symptoms such as dizziness, nausea, vomiting and imbalance together (1-4).

Vertigo is caused by disorders in the pathway or structures between the vestibular nuclei of the brainstem and the vestibular apparatus in the inner ear. The vestibular apparatus consists of three semicircular canals (anterior, posterior and lateral), and two autolytic organs; utricle and saccule. Semicircular canals perceive angular motion changes and speed in all directions in the three-dimensional space, such as the head's rotation, bending and twisting motion. The utricle perceives linear head movements in the horizontal plane more often, while the saccule perceives linear head movements in the vertical plane mostly. In this way, balance is created. Dysfunctions in these structures cause the appearance of vertigo and/or an imbalance table (1,5-7).

Vestibulo-ocular reflex is a reflex that creates eye movements in response to the rotating movements of the head for the image to be focused and clarity. Semicircular canals detect changes in the head position and transmit alerts that will allow the eyes to shift in the same direction and opposite the head movement direction. In case of dysfunction, eye movement, that is nystagmus arises that are not synchronised with the change in head movement. Nystagmus is used in the diagnostic tests of vertigo (1,5-7).

Video head impuls test (VHIT) has been developed in the diagnosis of peripheral vertigo caused by disorders related to semicircular canals (8). In previous methods, the eye movements in nystagmus, which were received in response to sudden head push warnings in the clinical setting, were interpreted subjectively by the staff performing the application. However, in the VHIT method, using high resolution and fast shooting cameras, eye movements that occur reflexively against sudden pushes of the head in different planes can be measured objectively, clearly and numerically. In addition, this method can be easily applied near the patient (8-12).

The VHIT has been performed on adults for years, and normal ranges for adults have been established $(13,14)$. In recent years, the applicability of this application on children has been investigated, and normal value ranges have been tried to be determined for these age group $(15,16)$. However, there is no study conducted on VHIT application and its results on children in Turkey. Our study aimed to examine vHIT in children with normal hearing function, and to determine normal value ranges.

\section{Methods}

This was a retrospective study, approved by University of Health Sciences Turkey, İstanbul Training and Research Hospital Ethical Committee with the number of 2239 (date: 27.04.2020). Medical records including audiovestibular test results were reviewed. Informed consent was obtained from parents of all patients.

\section{Patients}

A total of 78 patients under 16 years of age with normal hearing function and who had applied to our hospital's Otorhinolaryngology clinic for control were included in the study. The patients were divided into four groups as 4-6 years, 7-9 years, 10-12 years and over 12 years old (15).

Patients with a hearing or balance complaint or history, chronic disease, with long-term drug use and those with a head injury were not included in the study.

\section{Tests}

VHIT measurements were performed using the OTOsuite Vestibular software (Software Version: 3.00 Build 1007, Otometrics) and highspeed $\left(250 \mathrm{~Hz}\right.$ ) infrared camera (EyeSee Cam ${ }^{\mathrm{TM}}$ system Interacoustics A/S, Denmark ${ }^{\mathrm{T} M}$ ) mounted on special glasses (Type-1085 ICS impulse).

In the evaluation of the lateral semicircular canals, the head position was bent forward by 30 degrees, and head pushing movements were applied to the right and left at angles of 15 degrees, with the back of the jaw being fully grasped. In the vertical semicircular canals, the head thrust movement was applied by rotating the head position 45 degrees to the right or left in order to stimulate the vertical channels while the children were asked to be looking at the target points on both sides. At these stages, the test was completed by applying five head pushing movements for each channel, and vestibulo-ocular reflex gain values of six semicircular channels were determined.

\section{Statistical Analysis}

All statistical analyses in the study were done using SPSS 25.0 software (IBM SPSS, Chicago, IL, USA). Descriptive data are presented as numbers and percentages. In terms of categorical variables, comparisons between groups were made using Pearson's chi-square test and Fisher's Exact test. Whether the continuous variables are suitable for normal distribution was confirmed using the Kolmogorov-Smirnov test. The differences between the groups in terms of continuous variables were performed using the Student's t-test and the comparison of mean values between multiple groups was done by variance analysis. The results were evaluated within the $95 \%$ confidence interval and $p<0.05$ values were considered significant. Bonferroni correction was made where appropriate.

\section{Results}

Of the children participating in the study, 44 (56.4\%) were boys and 34 (43.6\%) were girls. Twelve (15.4) of the children were 4-6 years, 15 (19.2\%) were $7-9$ years, 16 (20.5\%) were $10-12$ years and 35 (44.9\%) were over 12 years old. Gender distributions were similar between the groups $(p=0.384)$ (Table 1).

\begin{tabular}{|l|l|l|l|}
\hline \multicolumn{3}{|l|}{ Table 1. Sex distribution by age groups } \\
\hline Age groups (years) & Male & Female & Total \\
\hline $4-6$ & 5 & 7 & 12 \\
\hline $7-9$ & 10 & 5 & 15 \\
\hline $10-12$ & 11 & 5 & 16 \\
\hline$>12$ & 18 & 17 & 35 \\
\hline Total & 44 & 34 & 78 \\
\hline$p=0.384$ & & & \\
\hline
\end{tabular}


There were no significant differences in the results of the vHITs among the ages of 4-6, 7-9 and 10-12 in terms of mean left lateral, right lateral, left anterior, right posterior, left posterior and right anterior values ( $p>0.05$ for each). However, in the analysis performed by combining the 4-12 age groups, a significant difference was found between the 4-12 age group and the above 12 age group in terms of left posterior mean values ( $p=0.012$ ) (Table 2). In Table 3, the mean \pm standard deviation values for the 4-12 age range reported from different studies and the present study are shown.

\section{Discussion}

VHIT is a method that provides objective data regarding the vestibuloocular reflex. VHIT is the only method that can evaluate the anterior and posterior semicircular canals individually in both ears. It was also stated that the vHIT method was the most valuable method in the evaluation of the horizontal canal vestibulo-ocular reflex $(1,8,17)$. It has been reported that the VHIT method is useful in differentiating central or peripheral causes of acute vertigo syndrome, it can evaluate at physiological and high frequencies, and it is being used more commonly in emergency departments (1). In addition, it has been stated that this method can be superior to other methods in terms of being a non-invasive method, providing high accuracy data, not being affected by middle and outer ear problems, evaluating the ears and semicircular canals separately, being easy and fast to apply and being applicable in children $(1,5,8)$.

There are limited reports on the use of the vHIT in adults. In recent years, studies on the usability of the VHIT in children have been started $(15-18,19)$. Ross and Helminski (19) reported that the re-applicability of the vHIT method in the child population is good. Those researchers also stated that the VHIT method provided reliable data in children, although their sensitivity and specificity regarding vestibular disorder were not high enough (19). Tozar et al. (16) found no significant difference in terms of mean vestibulo-ocular reflex gain values measured using the VHIT method in terms of the control group in children with otitis media and dizziness. Those researchers stated that symptoms of otitis media and dizziness did not result in the detection of vestibular disorders using the VHIT method (16). Nassif et al. (20) also found no significant difference in terms of the mean vestibulo-ocular reflex gain values measured using the vHIT method between the children with cochlear implants and the controls, but they stated that the number of patients was low. Zhou et al. (21) found that the vHIT test performed with a head tilt angle below $100^{\circ}$ may not show the loss of function in the semicircular canal in most patients, and $\mathrm{VHIT}$ tests not exceeding the $150^{\circ}$ angle may cause false negative results. However, these researchers stated that the $150^{\circ}$ head angle could not be applied in children. Hülse et al. (22) reported that the

Table 2. Comparison between age groups in terms of mean \pm standard deviation values of the vestibulo-ocular reflex gain obtained using the video head impuls test

\begin{tabular}{|c|c|c|c|c|c|c|c|}
\hline \multirow{2}{*}{ Age groups } & \multirow{2}{*}{$n$} & \multicolumn{2}{|c|}{ Lateral } & \multicolumn{2}{|c|}{ Anterior } & \multicolumn{2}{|c|}{ Posterior } \\
\hline & & Left & Right & Left & Right & Left & Right \\
\hline $4-6$ & 12 & $0.93 \pm 0.08$ & $1.01 \pm 0.12$ & $0.79 \pm 0.13$ & $0.88 \pm 0.1$ & $0.83 \pm 0.1$ & $0.73 \pm 0.09$ \\
\hline $7-9$ & 15 & $0.91 \pm 0.06$ & $0.95 \pm 0.08$ & $0.85 \pm 0.15$ & $0.79 \pm 0.14$ & $0.79 \pm 0.12$ & $0.78 \pm 0.11$ \\
\hline $10-12$ & 16 & $0.92 \pm 0.07$ & $0.95 \pm 0.06$ & $0.77 \pm 0.17$ & $0.87 \pm 0.15$ & $0.81 \pm 0.14$ & $0.7 \pm 0.14$ \\
\hline$p^{*}$ & & 0.654 & 0.214 & 0.387 & 0.182 & 0.772 & 0.235 \\
\hline $4-12$ & 43 & $0.92 \pm 0.07$ & $0.97 \pm 0.09$ & $0.8 \pm 0.15$ & $0.84 \pm 0.14$ & $0.81 \pm 0.12$ & $0.74 \pm 0.12$ \\
\hline$>12$ & 35 & $0.92 \pm 0.1$ & $0.99 \pm 0.1$ & $0.83 \pm 0.12$ & $0.82 \pm 0.17$ & $0.74 \pm 0.12$ & $0.75 \pm 0.12$ \\
\hline$p^{* *}$ & & 0.819 & 0.199 & 0.409 & 0.48 & 0.012 & 0.706 \\
\hline
\end{tabular}

One-Way ANOVA method has been used. *This is an analysis between 4-6, 7-9 and 10-12 age groups. ** This is an analysis made between 4-12 and 12 years old groups

Table 3. Comparison between age groups in terms of mean \pm standard deviation values of the vestibulo-ocular reflex gain obtained using the video head impuls test

\begin{tabular}{|c|c|c|c|c|c|c|c|}
\hline \multirow{2}{*}{ Age groups } & \multirow{2}{*}{ n } & \multicolumn{2}{|c|}{ Lateral } & \multicolumn{2}{|c|}{ Anterior } & \multicolumn{2}{|c|}{ Posterior } \\
\hline & & Left & Right & Left & Right & Left & Right \\
\hline Present study & 43 & $\begin{array}{l}0.92 \pm 0.07 \\
(0.82-1.16)\end{array}$ & $\begin{array}{l}0.97 \pm 0.09 \\
(0.84-1.33)\end{array}$ & $\begin{array}{l}0.8 \pm 0.15 \\
(0.37-1.08)\end{array}$ & $\begin{array}{l}0.84 \pm 0.14 \\
(0.58-1.1)\end{array}$ & $\begin{array}{l}0.81 \pm 0.12 \\
(0.42-1.02)\end{array}$ & $\begin{array}{l}0.74 \pm 0.12 \\
(0.54-1.1)\end{array}$ \\
\hline Bachmann et al. (15) & 30 & $\begin{array}{l}0.96 \pm 0.09 \\
(0.79-1.14)\end{array}$ & $\begin{array}{l}1.04 \pm 0.09 \\
(0.87-1.23)\end{array}$ & $\begin{array}{l}0.80 \pm 0.11 \\
(0.58-1.02)\end{array}$ & $\begin{array}{l}0.90 \pm 0.19 \\
(0.53-1.27)\end{array}$ & $\begin{array}{l}0.91 \pm 0.14 \\
(0.65-1.18)\end{array}$ & $\begin{array}{l}0.83 \pm 0.09 \\
(0.65-1.01)\end{array}$ \\
\hline Tozar et al. (16)* & 30 & $0.97(0.73-1.35)$ & $1.06 \pm 0.22$ & $0.95 \pm 0.22$ & $0.86(0.71-1.26)$ & $0.95 \pm 0.23$ & $0.95(0.87-1.35)$ \\
\hline Kidd et al.** & - & $\begin{array}{l}0.98 \pm 0.10 \\
(0.82-1.14)\end{array}$ & $\begin{array}{l}1.04 \pm 0.11 \\
(0.85-1.21)\end{array}$ & - & - & - & - \\
\hline
\end{tabular}

*Some data could not be reached, it covers the ages of 4-15. **Unpublished data; Kidd C, Byrd S, Riska K, Murnane 0, Akin F. (2014) Intra-and inter-examiner reliability of the video head impulse test. http://icsimpulse.com/blog/wp-content/uploads/Inter-Intra-Reliability-VA-Mountain-Home.pdf 
VHIT method was a sensitive and an effective test in children. Hamilton et al. (18) stated that the vHIT method was very effective and useful in determining the semicircular canal functions in children. These researchers also added that this method had many advantages over the gold standard rotary chair and caloric test methods. It was emphasised that there is need to conduct studies on determining the normal values of VHIT in children $(17,18)$. These data show that although there are some limitations in the implementation of the vHIT method in children, it can be used to quantify semicircular canal functions in this population.

Tozar et al. (16) determined the normal values of the vestibuloocular reflex gain for children using the VHIT method in their studies. Bachmann et al. (15) also applied the VHIT method in children to determine the normal values of the vestibulo-ocular reflex gain. The researchers divided the participants into 4-6, 7-9 and 10-12 age groups, and could not find any difference between the groups in terms of the VHIT values. In our study, the VHIT method was used and vestibuloocular reflex gain normal values were determined for healthy children aged 4-12 years (Table 3). It is seen that the mean normal values of all these studies are very close to each other. Similarly, it is observed that the obtained minimum and maximum values are close to each other between the studies. These findings show that the normal values of the vestibulo-ocular reflex gain obtained for healthy children in our study are reliable to be used by clinicians.

It has been shown that there may be differences in vestibulo-ocular reflex gain values between children and adults (15). Bachmann et al. (15) found that some vHIT values were significantly higher in the child group in comparison to the adult groups included in the study. In our study, it was observed that there was a significant difference between the children groups and the group over the age of 12 in terms of the left posterior vestibulo-ocular reflex value. These differences between children and other groups indicate the need to establish a normal vestibulo-ocular reflex gain value table for healthy children apart from adults.

There were some limitations in our study. Considering the difficulty of applying the VHIT test, children under the age of 4 were not included in the study, in line with the recommendations of some previous studies $(15,17)$. In parallel, in our study, vHIT normal values for the paediatric population between the ages of 4-12 were determined. Further investigations on younger age groups needs to be conducted.

\section{Conclusion}

When the findings of our study and combined reports were evaluated, it was observed that normal vestibulo-ocular reflex gain values should be determined in the paediatric population using the VHIT method. We consider that the findings of our study may be a guide for the evaluation of the vestibular function in children by paediatricians. Extensive studies are needed to ensure that the normal value ranges reach a higher level of reliability.

\section{Ethics}

Ethics Committee Approval: This was a retrospective study, approved by the Ethics Committee of the University of Health Sciences Turkey,
İstanbul Training and Research Hospital Ethics Committee (decision no: 2239, date: 27.04 .2020 ).

Informed Consent: Informed consent was obtained from parents of all patients.

Peer-review: Externally peer-reviewed.

Authorship Contributions: Surgical and Medical Practices - A.P.Y., K.H.K., A.K.K., M.S.E.; Concept - A.P.Y., H.E.K., M.S.E.; Design - A.P.Y., H.E.K., M.K.; Data Collection or Processing - A.P.Y., L.K., M.K., A.K.K., M.S.E.; Analysis or Interpretation - A.P.Y., L.K., K.H.K., A.K.K..; Literature Search - A.P.Y., L.K., H.E.K., M.K., A.K.K., M.S.E.; Writing - A.P.Y., K.H.K., M.S.E.

Conflict of Interest: No conflict of interest was declared by the authors.

Financial Disclosure: The authors declared that this study received no financial support.

\section{References}

1. Temirbekov D. Current practice in vertigo and dizziness. Curr Pract ORL 2018; 14: 10-20.

2. Wipperman J. Dizziness and vertigo. Prim Care 2014; 41: 115-31.

3. Choi JY, Lee SH, Kim JS. Central vertigo. Curr Opin Neurol 2018; 31: 81-9.

4. Li Y, Peng B. Pathogenesis, Diagnosis, and treatment of cervical vertigo. Pain Physician 2015; 18: E583-95.

5. Blödow A, Bloching M, Hörmann K, Walther LE. Receptor function of the semicircular canals. Part 2: pathophysiology, diseases, clinical findings and treatment aspects. HNO 2012; 60: 249-59.

6. Rabbitt RD. Semicircular canal biomechanics in health and disease. J Neurophysiol 2019; 121: 732-55.

7. Omron R. Peripheral Vertigo. Emerg Med Clin North Am 2019; 37: 11-28.

8. Halmagyi GM, Chen L, MacDougall HG, Weber KP, McGarvie LA, Curthoys IS The Video Head Impulse Test. Front Neurol 2017; 8: 258.

9. Kokten N, Karaca S, Incesulu A. Kalcıoğlu T. A new and objective test to evaluate functions of the semicircular canals: A review of video head impulse test. Kulak Burun Bogaz Ihtis Derg 2017; 27: 241-50.

10. Welgampola MS, Taylor RL, Halmagyi GM. Video head Impulse testing. Adv Otorhinolaryngol 2019; 82: 56-66.

11. Chen L, Halmagyi GM. Video Head Impulse Testing: From Bench to Bedside. Semin Neurol 2020; 40: 5-17.

12. Alhabib SF, Saliba I. Video head impulse test: a review of the literature. Eur Arch Otorhinolaryngol 2017; 274: 1215-22.

13. McGarvie LA, MacDougall HG, Halmagyi GM, Burgess AM, Weber KP, Curthoys IS. The Video Head Impulse Test (VHIT) of Semicircular Canal Function-AgeDependent Normative Values of VOR Gain in Healthy Subjects. Front Neurol 2015; 6: 154

14. Matiño-Soler E, Esteller-More E, Martin-Sanchez JC, Martinez-Sanchez JM, Perez-Fernandez N. Normative data on angular vestibulo-ocular responses in the yaw axis measured using the video head impulse test. Otol Neurotol 2015; 36: 466-71.

15. Bachmann K, Sipos K, Lavender V, Hunter LL. Video Head Impulse Testing in a Pediatric Population: Normative Findings. J Am Acad Audiol 2018; 29: 417-26.

16. Tozar M, Cömert E, Șencan Z, Şimşek G, Muluk NB, Kılıç R. Video head impulse test in children with otitis media with effusion and dizziness. Int J Pediatr Otorhinolaryngol 2020; 129: 109783. 
17. Bartolomeo M, Biboulet R, Pierre G, Mondain M, Uziel A, Venail F. Value of the video head impulse test in assessing vestibular deficits following vestibular neuritis. Eur Arch Otorhinolaryngol 2014; 271: 681-8.

18. Hamilton SS, Zhou G, Brodsky JR. Video head impulse testing (VHIT) in the pediatric population. Int J Pediatr Otorhinolaryngol 2015; 79: 1283-7.

19. Ross LM, Helminski JO. Test-retest and Interrater Reliability of the Video Head Impulse Test in the Pediatric Population. Otol Neurotol 2016; 37: 558-63.
20. Nassif N, Balzanelli C, Redaelli de Zinis LO. Preliminary results of video Head Impulse Testing (vHIT) in children with cochlear implants. Int J Pediatr Otorhinolaryngol 2016; 88: 30-3.

21. Zhou G, Goutos C, Lipson S, Brodsky J. Range of Peak Head Velocity in Video Head Impulse Testing for Pediatric Patients. Otol Neurotol 2018; 39: e357-61.

22. Hülse R, Hörmann K, Servais JJ, Hülse M, Wenzel A. Clinical experience with video Head Impulse Test in children. Int J Pediatr Otorhinolaryngol 2015; 79: 1288-93. 